Pedro Paulo Da Poian

\author{
Uso Sustentável de \\ Áreas Naturais Protegidas Urbanas
}

Dissertação de Mestrado

Dissertação apresentada ao Programa de Mestrado Profissional em Engenharia Urbana e Ambiental da PUCRio, como requisito parcial para a obtenção do título de Mestre

Orientador: Prof. Luiz Felipe Guanaes Rego

Co-orientador: Prof. David Man Wai Zee 
Pedro Paulo Da Poian

\section{Uso Sustentável de Áreas Naturais Protegidas Urbanas}

Dissertação apresentada como requisito parcial para a obtenção do grau de Mestre pelo Programa de Mestrado Profissional em Engenharia Urbana e Ambiental da PUC Rio, aprovada pela Comissão Examinadora abaixo assinada.

Prof. Luiz Felipe Guanaes Rego, Orientador Departamento de Geografia - PUC- Rio

Prof. David Man Wai Zee, Co-orientador Departamento de Oceanografia Física - UERJ

Profa. Aspásia Camargo Departamento de Sociologia e Ciência Política - UERJ

Prof ${ }^{a}$ Danielle Andrade Moreira Departamento de Direito Ambiental - PUC- Rio

Prof Rogério Ribeiro de Oliveira Departamento de Geografia e Meio Ambiente - PUC- Rio

Prof. José Eugênio Leal Coordenador Setorial de Pós-Graduação do CTC -PUC- Rio

Rio de Janeiro, 4 de novembro de 2013 
Todos os direitos reservados. É proibida a reprodução total ou parcial do trabalho sem autorização da Universidade, do autor e do Orientador.

\section{Pedro Paulo Da Poian}

Graduou-se em Engenharia Civil na Escola de Engenharia da PUC-Rio em 1961. Especialização em Refinação de Petróleo, UFRJ / Petrobrás, em 1962. Cursos de Técnicas de Elaboração e Análise de Projetos de Investimento e de Gerência Financeira, IAG / PUC / RJ, em 1968 e 1970. Curso International Executive Programme, INSEAD/ França, em 1984. Especialização em Gestão da Inovação para o Desenvolvimento Local, UFF/Univ. de Milão, em 2007/2008. Trabalhou de 1963 a 1971 na Petrobrás, de 1972 a 1980 no Grupo Ultra, de 1980 a 1992 na Norquisa, de 1992 a 1998 na Petroflex, de 1998 a 2008 na Previnor, em funções técnicas e de direção. Desenvolveu trabalhos como Consultor e Professor, além de participar de inúmeros Congressos e Seminários.

Ficha Catalográfica

Da Poian, Pedro Paulo

Uso sustentável de áreas naturais protegidas urbanas; Pedro Paulo Da Poian ; orientador: Luiz Felipe Guanaes Rego ; co- orientador: David Man Wai Zee. - 2013.

107 f. : il. (color.) ; $30 \mathrm{~cm}$

Dissertação (mestrado)-Pontifícia Universidade Católica do Rio de Janeiro, Departamento de Engenharia Civil, 2013.

Inclui bibliografia

1. Engenharia civil - Teses. 2. Engenharia urbana e ambiental. 3. Áreas naturais protegidas. 4. Uso sustentável. 5. Ecoturismo. 6. Lazer ecológico. 7. Parque Marapendi/RJ. I. Rego, Luiz Felipe Guanaes. II. Zee, David Man Wai. III. Pontifícia Universidade Católica do Rio de Janeiro. Departamento de Engenharia Civil. Programa de Pós-Graduação em Engenharia Urbana e Ambiental. IV. Título. 


\section{Agradecimentos}

Ao meu Orientador, Prof. Luis Felipe Guanaes Rego e ao meu Co-orientador, Prof David Man Wai Zee, pelo estímulo e ajuda para o desenvolvimento desse trabalho.

Aos professores, colegas e pessoal de secretaria do Curso de Pós-Graduação em Engenharia Urbana e Ambiental da PUC-Rio.

Aos professores que participaram da comissão examinadora.

À minha esposa, familiares e amigos que me apoiaram nessa empreitada. 


\section{Resumo}

Da Poian, Pedro Paulo; Rego, Luiz Felipe Guanaes; Zee, David Man Wai. Uso Sustentável de Áreas Naturais Protegidas Urbanas. Rio de Janeiro, 2013, 107 p. Dissertação de Mestrado - Departamento de Engenharia Civil, Pontifícia Universidade Católica do Rio de Janeiro.

A criação de Áreas Naturais Protegidas foi um movimento iniciado no final do século XIX e difundiu-se por todo o mundo ao longo do século XX, sendo, em 1960, criada a Comissão Mundial de Parques Nacionais e Áreas Protegidas (WCPA). Em 1937 foi criada a primeira e efetiva Área Natural Protegida brasileira - o Parque Nacional de Itatiaia /RJ. A Lei n ${ }^{\circ} 9.985$ criou no ano 2000 o Sistema Nacional de Unidades de Conservação (SNUC). A conservação das Áreas Naturais Protegidas enfrenta inúmeras dificuldades por todo o mundo sendo vários os exemplos de "parques de papel", que são criados mas nos quais quase nada é feito. Mas as medidas relativas à regularização fundiária, à implantação de infra-estrutura, à existência de funcionários e ao funcionamento de esquemas de gestão participativa não são por si só suficientes para garantir a efetiva conservação das Áreas Protegidas; é fundamental a adoção de mecanismos de "Uso Sustentável" dessas áreas, fomentando sua visitação, de forma ordenada e racional. Os usuários, conscientizados da importância da conservação ambiental, tornam-se efetivos fiscais do Parque. Nos Parques mais distantes dos centros urbanos e onde a vida selvagem está mais preservada, seu "Uso Sustentável" é assegurado pelo ecoturismo. No caso das Áreas Naturais Protegidas Urbanas, ganha destaque o "Lazer Ecológico", com atividades ligadas à recreação, relaxamento, contemplação, etc. $\mathrm{O}$ trabalho analisa a situação do "Uso Sustentável" dos principais Parques do município do Rio de Janeiro e detalha as ações necessárias no Parque Natural Municipal Marapendi para que o mesmo possa efetivamente tornar-se um Parque de "Uso Sustentável".

\section{Palavras-chave}

Áreas naturais protegidas; uso sustentável; ecoturismo; lazer ecológico; Parque Marapendi/RJ. 


\section{Extended Abstract}

Da Poian, Pedro Paulo; Luiz Felipe Guanaes; Zee, David Man Wai. Sustainable Use of Urban Protected Natural Areas. Rio de Janeiro, 2013, 107 p. MSc. Dissertation - Departamento de Engenharia Civil, Pontifícia Universidade Católica do Rio de Janeiro.

\section{Introduction}

Since ancient times man used to protect certain areas for religious or historical reasons, but from the nineteenth century the main objective of protecting natural areas became the preservation of scenic beauty and ecological purposes.

It was thus consolidated the concept of Natural Protected Areas, which are called today, in Brazil, of Conservation Units. Although most extent of these areas are situated outside cities environments, there are also Urban Protected Areas, of enormous importance.

Over the decades, however, many parks created in Natural Protected Areas became just paper parks, not reaching their purposes.

\section{Objectives}

We have conducted an exploratory qualitative research on Natural Protected Areas, with the general objective to prove that for these areas fulfill their role, it is not enough to have sound infrastructure or management mechanism, that includes effective community participation, but it is indispensable to develop action plans that are based on their sustainable use, with an emphasis on ecotourism.

As Specific Objective of the study we have chosen an Urban Protected Natural Area - the Marapendi Natural Municipal Park / RJ to evaluate the problems that are hampering the implementation of the Park, to propose solutions to these problems, and indicate how to achieve their sustainable use. 


\section{Development}

The creation of Yellowstone National Park in the United States in 1872 was a milestone for the protection of natural areas. Since then the trend to create Protected Natural Areas overspread the more developed countries, extending up subsequently to the emerging countries.

Nearly 50 years after the creation of Yellowstone there was not in the world an uniform view of the objectives of the creation of National Parks, and only in 1933 was held in London one UN Convention to discuss the matter. Only in 1992, a World Congress on National Parks, established a set of protected areas categories, which exists to this day.

There are several successful experiments for the preservation of natural parks in tropical areas. In 1999, at the meeting "Making Parks Work", held in the United States, it became clear that the previously position for the preservation of nature in its wild state had given way to management practices that viewed the sustainable use of living resources as an equivalent conservation. Emphasis has shifted fromprotection and exclusion for the sustainable use and prevention of degradation and depletion.

\section{Brazilian Parks history}

The first proposals for parks creation in Brazil dates from 1876, but only in 1937 it was created the first effective Brazilian Natural Protected Area - the Itatiaia National Park, in Rio de Janeiro.

In 1989 it was drafted a proposal for a National System of Conservation Units SNUC. After long discussion at the Congress, the proposal was approved, on July 2000 , in the form of the Law $n^{\circ} 9.985$.

The debate exposed clearly the differences between the preservationist current and conservationist current. For the first group the creation of legally protected areas was the best guarantee against industrial development. On the other hand, conservationists defended the rational use of natural resources, in order to integrate the conservation area with the society in which it is inserted.

In 2010, ten years after the creation of SNUC, Brazil registered the existence of 310 Federal Conservation Units and 388 State Conservation Units. Brazil had the fourth largest land area covered by protected areas in the world, with 1.278 million $\mathrm{km}^{2}$, only behind the United States, Russia and China. 
Despite this prominent position on the international scene, the SNUC effective implementation faces several problems: the land tenure regularization, lack of staff and basic infrastructure, the absence of a management plan, among others. The investment insufficiency is the main cause of most of these problems, which may be aggravated by the prospect of integration of new units at the System in the coming years.

Overcoming the investment problems noted above is not, however, sufficient to be achieved sustainable use of natural protected areas; it's fundamental to develop ecotourism and ecological leisure. There are numerous activities that can be developed in a ecotourism program in forest areas where wildlife is prevalent. In the specific case of Urban Protected Natural Areas, the prominence is for ecological leisure activities.

From the end of the 90s the Federal Government initiated a project aimed at the sustainable use of National Parks, offering concessions of various services to private entrepreneurs. One of the first Brazilian Parks where the Sustainable Use has been successfully deployed was the Iguaçu Falls National Park. Continuous investment in quality service to tourists, combined with dissemination actions have helped the Park to hit successive records in annual visitation.

\section{Rio de Janeiro City view}

In what concerns of Federal Natural Parks at the State of Rio de Janeiro, the Tijuca Park is the only located in the city of Rio de Janeiro. It is also the most visited National Park in Brazil. Through the years, the Tijuca National Park became an important recreation area, providing means for sports and contemplation of nature, adopting practices of Sustainable Use. Therein lie some landmarks and symbols of the city of Rio de Janeiro, and even the country, such as the Christ the Redeemer statue.

The Government of the State of Rio de Janeiro, following the example of the Federal Government, has established guidelines for public use in the 11 State Parks administered by the State Environmental Institute - INEA. There are three State Parks located in the city of Rio de Janeiro, and only one - the Pedra Branca Park, deserves special mention. It is regarded as the largest forest reserve in urban areas in the world, but it has many shortcomings with regard to its sustainable use. 
And none of the 15 Municipal Natural Parks (PNM's) presents characteristics of Sustainable Use.

\section{History of PNM Marapendi}

The PNM Marapendi lies surrounding the Marapendi Lagoon, that is part of the Jacarepaguá Lagoon Complex, one of the most important ecosystems in the municipality of Rio de Janeiro.

Since the 1930s emerged demands for the creation of a biological reserve in the region; in 1959, it was created the Jacarepaguá Biological Reserve, transformed in 1961 into Zoobotanical Park, with around 400 thousand square meters, the latter date being considered as the mark of the creation of the Marapendi Park.

Over the following years some equipment were implanted, the area was surrounded and hiking trails were opened. The Park began offering guided tours on the trails, technical consultations, workshops and recycling art, exhibitions, lectures, video presentations, training teachers. was also deployed a Centre for Excellence in Environmental Education. The Park now has a manager, although the Advisory Board, required by the law, so far has not been formed. We can say that the Park Zoobotânico Marapendi, despite its small size and limitations, has become a reasonable an Urban Protected Natural Area, with Sustainable Use.

In 1991 was created the Park Environmental Protection Area-APA of the Zoobotânico Marapendi Park, including the Park and the protective strip from the waterfront. The APA creation, a victory of the struggle that was being waged for years by local residents, came to unify areas that were previously protected by fragmented legislation.

During the Barra da Tijuca expansion process, some real estate developments were accompanied by a donation to the Municipality of areas on the edge of the lagoon. The mayor of the city, in 1995, transformed the Zoobotânico Marapendi Park into the Marapendi Ecological Municipal Park and incorporated to it all public areas of the lagoon north bank, which totaled around 1.2 million $\mathrm{m}^{2}$. Thus, 
the north shore of the lagoon became occupied by a large park, with a total area of around 1.6 million $\mathrm{m}^{2}$.

But in the followed years nothing was done in the expanded significantly Marapendi Park. Even the fencing of the area continued to cover only the area of the original Zoobotanical Park. Only the name of the Park was changed in 2003 to Marapendi Natural Municipal Park.

\section{The PNM Barra da Tijuca}

The narrow strip of land that separates the Lagoon from Lucio Costa Avenue, at the seashore, formed by lots of private property which integrates APA Marapendi but not the Park, should have been subject of a governmental action to be incorporated to it, since the law of the land use in this area was extremely restrictive, having been established when it was created the Marapendi Park APA's.

For over 10 years these parameters become economically unattractive buildings in the area, that has been degraded with the proliferation of various irregular parking. Real estate interests moved intensely until the City Council approved in 2005 a project easing the constructive parameters.

Popular reactions arose in relation to the approval of the new law and the Mayor, in 2011, transformed the strip of land between the lagoon and the beach, with around 1.8 million $\mathrm{m}^{2}$, in the Municipal Natural Park of Barra da Tijuca, prohibiting the licensing of any construction in that area. This measure has generated reactions and a project is still in the City Council to resolve disputes.

This transformation of the range between the lagoon and the beach in a park is a step forward in the process of enabling the use of the Marapendi APA area. It seems, however, that the ideal solution would be the annexation of the area of the new park to Marapendi Park, which would then embrace all Marapendi Lagoon. The two parks together, would have an area of 3.4 million $\mathrm{m}^{2}$. To get an idea of the grandeur of this park, just compare the area mentioned with the 1.2 million $\mathrm{m}^{2}$ of Flamengo's Park. In addition, the Park is located around the Marapendi Lagoon, whose water surface is 3.6 million $\mathrm{m}^{2}$, while the water surface of the Rodrigo de Freitas Lagoon has 2.4 million $\mathrm{m}^{2}$. 
If the Sustainable Use of the current Marapendi PNM is, even if it is incomplete, limited to the area of the former Park Zoobotânico Marapendi, you can get an idea of the challenge to the effective implementation of the new Marapendi PNM (incorporating the Barra da Tijuca PNM).

\section{The Olympic Golf Course}

More recently the City announced the construction of a golf course in an area of the region, which would be used in the 2016 Olympic Games.

One obstacle to the deployment of Golf Course was that the area chosen, a part of Marapendi APA, was classified as a Wildlife Protection Zone, which would not allow such use. City claimed that it was a commitment for the Games in 2016 and the other golf fields of the City did not meet the standards required for an Olympics. Moreover, the owners and developers of buildings to be constructed next to the field, would assume the investment to be made (exempting the City) and would administer the space for 25 years, the use of which would not be exclusive to the nearby residents and may be frequented by other people.

A new legislation was approved, changing the area classification for a Conservation Zone, where some uses are permitted, and specifically authorizing the construction of a Golf Course in that area.

The way is thus open to deploying Olympic Golf Course which, although situated within the APA Marapendi, will not be part of the Marapendi Park, which will suffer a disruption on that site.

It seems that the ideal would be that, besides the preservation of patches of native vegetation remaining in the area, it were segregated in the project, a track on the Lagoon shore, which could be donated to the city, becoming a part of the Marapendi Park.

\section{The Lagoon remediation}

A serious project and comprehensive Sustainable Use of the Marapendi Park necessarily have to include the use of Marapendi Lagoon for water sports, boat crossings, ecological tours, etc.. For this de-pollution of the lagoon is critical. 
The major source of pollution of the Marapendi Lagoon are the drains from Recreio dos Bandeirantes poor communities, launched in the Tachas Channel. The Sewage Project for Barra da Tijuca and Recreio area, which is running, intend to collect all sewage of that area. It seems to be an extremely difficult goal to be achieved, but it has to be pursued as a priority.

\section{Illegal occupation}

Other difficulties for the effective implementation of the PNM Marapendi may be cited as the illegal occupation of part of the Park area by the Officers' Club of the Fire Department, the construction of a Pumping System of the Barra da Tijuca Sanitation Project in the Park, the installation of a telephone antenna within the area, the authorization for the operation of a regular school in an area where is only permitted the operation of clubs, as well as the occupation of parts of the marginal strip protection of the lagoon for some near condominiums.

\section{Previous attempts}

A first attempt to improve the Park's role occurred in 1996, when it was developed a pilot project, but limited to only one section of it.

With the creation of the Municipal Natural Park of Barra da Tijuca, local members of civil society, judged it to be the right time to go a step forward in the long process, and hired a draft Sustainable Use of that area, which was completed in May 2012. The Project is valid as a search for sustainable use, but covers only part of the total area of the Park.

\section{Conclusions}

The Urban Protected Natural Areas incentive to use it for leisure, recreation, the pursuit of physical well-being, etc.. is critical because their conservation will be more easily achieved if you meet the needs of the surrounding populations. So the users become government allies in protecting the area. This measure is also in accordance with the growing social pressure for better living conditions in the cities. 
For the implementation of measures aimed at the sustainable use of these areas is necessary to seek the awareness of managers, the support of government agencies related to the process, potential funders for the necessary investments and mobilizing society directly involved and benefited.

In the specific case of the PNM Marapendi, the adequate infrastructure, would require the installation of bathrooms, locker rooms, snack bars, gazebos, docks, etc.., taking due care in relation to water supply and the sewage and garbage collection.

The city of Rio de Janeiro, in spite of its natural beauty and beautiful beaches, lacks large green areas for recreation. Barra da Tijuca is the site of greatest growth of the city and, with the implementation of new expressways and the special buses lines BRT's (Transoeste, Transcarioca and Transolímpica), will be a center of convergence for the entire population of the West and much of the North Zone. A large park in the region will have enormous significance for the quality of life for a very significant portion of the population of Rio.

The effective implementation of the Marapendi Municipal Natural Park, as stated in the City Master Plan approved in 2012, and the annexation of the nearby Barra da Tijuca Municipal Natural Park, and its orientation towards seeking sustainable use practices, would be an extraordinary achievement for the city.

Although the reported problems and distortions, it would still be possible to provide the city, and in particular the West Zone, with an extraordinary leisure area. Therefore some proposals are noteworthy as the fencing of the area, the establishment of controlled access points, the preservation of native vegetation, effective action to remove the illegal occupation, the strict enforcement of the use of the areas that comprise the APA but not the Park, the search for a solution to the continuity of bike paths and trails on the edge of the lagoon, the complete sanitation of the entire Marapendi Lagoon, the immediate formation of the Advisory Board of the Park with qualified representatives of the three branches of power in society, the implementation of necessary infrastructure and the creation of a body-guard to the local parks.

As the Iguaçu National Park and Fernando de Noronha National Marine Park can be considered today examples of Sustainable Use of Natural Parks, the same happens, on a smaller scale, with the Tijuca National Park. And the Marapendi 
Municipal Natural Park meets all the basic conditions to be an Urban Protected Natural Area with a Sustainable Use, provided that the above measures are effectively implemented.

\section{Keywords}

Natural protected areas; sustainable use; ecotourism; ecological leisure; Marapendi Park / RJ. 


\section{Sumário}

1. Introdução

1.1. As Áreas Naturais Protegidas 20

1.1. Objetivo da Pesquisa 22

1.2. Delimitação da Área de Estudo 23

1.3. Relevância 23

1.4. Metodologia 24

1.5. Estrutura da Dissertação 24

2. Desenvolvimento

2.1. Breve histórico das Áreas Naturais Protegidas 26

2.2. A importância das Áreas Naturais Protegidas 30

2.3. Legislação brasileira 31

2.4. Dificuldades para a conservação da Áreas Naturais $\begin{array}{ll}\text { Protegidas } & 34\end{array}$

2.5. O Uso Sustentável das Unidades de Conservação 39

2.6. Ecoturismo e lazer ecológico no Brasil 42

2.7. Os Parques Naturais do Estado do Rio de Janeiro 46

2.8. Os Parques Naturais do Município do Rio de Janeiro 47

3. Estudo de caso: PNM Marapendi / RJ

3.1. Correlação com a Pesquisa 58

3.2. Descrição da área 58

3.3. Primeiras tentativas de proteção legal 62

3.4. A Reserva Biológica de Jacarepaguá e o Plano Lúcio Costa 
3.5. O Parque Zoobotânico de Marapendi 64

3.6. A criação da APA Marapendi 65

3.7. A transformação em Parque Ecológico Marapendi e a denominação de PNM Marapendi 68

3.8. A criação do PNM da Barra da Tijuca 69

3.9. O Campo de Golfe Olímpico 74

3.10. A Poluição da Lagoa de Marapendi 77

3.11. O Clube dos Bombeiros 80

3.12. A Elevatória Marapendi 81

3.13. Ocupações irregulares

3.13.1. Antena de telefonia celular 82

3.13.2. As ZOC's 2 da APA Marapendi 83

3.13.3. Outras ocupações irregulares 86

3.13.4. A ocupação das ilhas da Lagoa 88

3.14. Do papel à prancheta

3.14.1. O Projeto PLANAVE 88

3.14.2. O Projeto da Câmara Comunitária da Barra 89

4. Conclusão, Recomendações e Propostas

4.1. Conclusão 91

4.2. Recomendações 92

$\begin{array}{ll}\text { 4.3. Propostas } & 94\end{array}$

$\begin{array}{ll}\text { Referências bibliográficas } & 97\end{array}$

$\begin{array}{ll}\text { Bibliografia consultada } & 104\end{array}$ 


\section{Lista de Figuras}

Figura 1 - Cachoeira da Torre Creek - Parque de Yellowstone USA

Figura 2 - Sequóias gigantes - Parque de Yosemite - USA

Figura 3 - Número de funcionários por ha. protegidos no Brasil e em outros países

Figura 4 - Investimento por ha. de unidade de conservação em diferentes países

Figura 5 - Parque Nacional do Iguaçu - PR - Cataratas

Figura 6 - Parque Nacional Marinho de Fernando de Noronha PE - Morro Dois Irmãos

Figura 7 - Parque Nacional da Tijuca - Rio de Janeiro /RJ -

Corcovado

Figura 8 - Parque Estadual da Pedra Branca - Rio de Janeiro /

RJ - Cachoeira do Camorim

Figura 9 - PNM da Prainha - Rio de Janeiro /RJ

Figura 10 - Pão de Açúcar e Urca - Rio de Janeiro/RJ

Figura 11 - Penhasco Dois Irmãos - Rio de Janeiro/RJ

Figura 12 - PNM Bosque da Barra - Rio de Janeiro /RJ -

Capivaras

Figura 13 - PNM Chico Mendes - Rio de Janeiro /RJ

Figura 14 - Complexo Lagunar da Baixada de Jacarepaguá -

Rio de Janeiro /RJ

Figura 15 - Vista aérea do Complexo Lagunar - Rio de Janeiro / RJ

Figura 16 - Lagoa de Marapendi - Rio de Janeiro /RJ

Figura 17 - APA Marapendi - Rio de Janeiro /RJ

Figura 18 - PNM Barra da Tijuca - Rio de Janeiro /RJ 
Figura 19 - Beach Point do Condomínio Blue - Barra da Tijuca Rio de Janeiro/RJ

Figura 20 - Área prevista para o Campo de Golfe Olímpico - Rio de Janeiro /RJ

Figura 21 - Planta da área do Campo de Golfe Olímpico - Rio de Janeiro /RJ

Figura 22 - Canal das Tachas - Rio de Janeiro /RJ

Figura 23 - Poluição no fundo da Lagoa de Marapendi - Rio de Janeiro /RJ

Figura 24 - Lançamento de esgoto na Lagoa através da rede de águas pluviais (final da Av. Moysés Castello Branco Fon, ao lado do Condomínio Malibu) - Rio de Janeiro /RJ

Figura 25 -Clube dos Oficiais Bombeiros (atrás do Condomínio Novo Leblon) - Rio de Janeiro /RJ

Figura 26 - Elevatória Marapendi (atrás do Condomínio Park Palace) - Rio de Janeiro /RJ

Figura 27 - Antena Telefonia Celular no do Parque Marapendi (no final da Rua Prof. Alfredo Colombo) - Rio de Janeiro /RJ

Figura 28 - Union Church e Rio International School (atrás do Condomínio Nova Ipanema) - Rio de Janeiro /RJ

Figura 29 - Escola Carolina Patrício (atrás do Condomínio Novo Leblon) - Rio de Janeiro /RJ

Figura 30 - Construção irregular na área do Clube Ginástico Português (atrás do Condomínio Barra Bali) - Rio de Janeiro /RJ 85 Figura 31 - Fazendinha (atrás do Condomínio Novo Leblon) Rio de Janeiro /RJ

Figura 32 -- Quadras de Vôlei (atrás do Condomínio Novo Leblon) - Rio de Janeiro /RJ 86

Figura 33 - Feirinha instalada atrás do Condomínio Mandala - 
Rio de Janeiro /RJ

Figura 34 - Projeto da CCBT para o PNM Barra da Tijuca - Rio de Janeiro 